\title{
Vendor Selection using Analytical Network Process (ANP) in Heavy Equipment Company
}

\author{
M. Yanie Syafei \\ President University, Indonesia \\ yanisyafei@president.ac.id \\ Anastasya Lidya Maukar \\ President University, Indonesia \\ almaukar@president.ac.id \\ Hening Herziatra \\ President University, Indonesia \\ herziatrahening@gmail.com
}

\begin{abstract}
Using qualitative interviews to understand the mindset of family business leaders in succession, this Supply Chain Management is important in industry. Vendor is the key component in the supply chain flow. A company abbreviated as UTPE is one of the biggest manufacturing companies in Indonesia that produces heavy equipment. The main materials are plates and spare parts that have been supplied by eight vendors. The current system of vendor selection is based on tardiness of delivery time, but every vendor has different frequency of delivery so that it cannot be compared. Therefore, the appropriate criteria and sub criteria are required to create a new system of vendor selection. The criteria and sub criteria are determined based on the previous research and interview with an expert in the company. There are 5 criteria and 17 sub criteria that are approriate for vendor selection. ANP is the development of Analytical Heuristic Process (AHP) by considering dependency between elements of hierarchy. By using ANP, the interdependency between criteria, sub criteria and their weight can be defined. Data collection is done by using observation, interview and questionnaire. Sub criteria long term relationship has the highest weight and vendor abbreviated as GH is the best vendor with score 3.057 of 5 .
\end{abstract}

Keywords: Supply Chain Management, Heavy Equipment, Tardiness, Vendor, ANP

\section{Introduction}

UTPE is one of the biggest manufacturing companies in Indonesia that produces heavy equipment. Procurement Department has the responsibility to order the needs of the company such as plates and spare parts. Therefore, the department that has to select the best vendor. In UTPE, vendor selection is based on the delivery achievement (tardiness of delivery time). The percentage of tardiness is defined by the ratio of total tardiness of vendor and the total of delivery. The total of delivery time for every vendor is different; it means that it is not relevant to select the vendor based on the percentage of tardiness. 
Based on the problem above, more criteria and sub criteria are needed in order to select the appropriate vendor that fits with the company needs thus the selectioncannot be based on the delivery time only. UTPE has eight vendors of plates and spare parts, which are $\mathrm{AB}, \mathrm{CD}, \mathrm{EF}, \mathrm{GH}, \mathrm{IJ}, \mathrm{KL}, \mathrm{MN}$, and $\mathrm{OP}$. From this variation of vendor, it needs additional criteria to make the result of vendor selection more accurate and more specific. Based on this situation, vendor selection Using Analytical Network Process is needed to determine the appropriate vendor in the company for future order. ANP is using in this method because by using ANP the dependency between Criteria and Sub Criteria can be define. By defining the dependency between criteria and sub criteria, the weight of every criterion and sub criterion can be determined more accurately. There are several objectives of this research, first is to determine the appropriate method for selecting suitable vendor of plate and spare part in this company. Second is to determine the criteria and sub criteria of vendor selection of plate and spare part in this company. Third is to determine interdependence between criteria and sub criteria of vendor selection of plate and spare part. Last is to determine the vendor ranking of plates and spare parts in this company.

\section{Literature review}

The theorem that used in this research are Supply Chain Management, Vendor Selection and Analytical Network Process. Those all theorem will be explained below.

\subsection{Supply Chain Management}

The definition of "supply chains" seems to be more common across authors than the definition of "supply chain management" (La Londe and Masters 1994; Lambert, Stock, and Ellram 1998). Supply chain is a set of firms that pass materials forward (La Londe and Masters 1994). Normally, several independent firms are involved in manufacturing a product and placing it in the hands of the end user in a supply chain - raw material and component producers, product assemblers, wholesalers, retailer merchants and transportation companies are all members of a supply chain (La Londe and Masters 1994).

Another definition notes that a supply chain is the network of organizations that are involved, through upstream and downstream linkages, in the different processes and activities that produce value in the form of products and services delivered to the ultimate consumer. In other words, Supply Chain Management is a way to organize the vendor with manufacturer, wholesaler, distributor, and retailer in the effective and efficiency way based on quantity accuracy, delivery time accuracy, and location accuracy in order to minimize the cost. Supply chain management helps people to be more efficient to distribute anything faster.

\subsection{Vendor Selection}

Vendor or suppliers is a company or anyone who sells product, can be in the form of raw material, goods, or services to customer in the economic production chain. Vendors are a main part of manufacturing since vendor sells the product that needed in manufacturing process. Vendor selection is the most crucial thing in manufacturing process. Supplier selection process should be suitable with the requirements of the customer in order to fulfill the needs and also to make profit of organization. The customer supplier relation both in the service organizations concerning to SCM in the service industry. 
Increasing the supply chain management will affect the organization to improve in purchasing activities. Organization is one of the most crucial part of the purchasing function is supplier selection (Tookey and Thiruchelvam 2011; Florez-Lopez 2007). The development of supply chain management as a part of a system is capable in facing market competition, and adequate set of competencies is required (Esposito and Passaro 2009).

\subsection{Reciprocal nepotism}

The method that used in this research is Analytical Network Process. Analytical network process is the development of analytical hierarchy process by considering the dependence between elements of hierarchy. The basic structure of analytical network process is an influence network of clusters and nodes contained within the clusters. Many problems cannot be conducted hierarchically because it involves the interaction and dependence of higher level elements in a hierarchy on lower level elements. Moreover, the ANP is conducted by a network, rather than a hierarchy.

This research is using three ways to collect the data. First is by doing some observation, second is by conducting some interview with an expert, and last is by using the questioner. The following steps are explains about the steps of ANP in this research (Mulyati, Erna and Faizal, Muhammad Abdul 2012):

\section{1) Initial Observation}

In this step, the observation is conducted. The objective of observation is to determine the current problem in procurement department.

\section{2) Identify Criteria and Sub Criteria}

This step is done by doing interview with an expert in Procurement Department. In this step, all criteria needed in procurement department to select the vendor is identified. Aside from doing interview with an expert, this step is also done by using literature study from previous research, journals, or books as references.

\section{3) Identify Interdependence between Criteria and Sub Criteria}

After identifying criteria and sub criteria, interdependence between Criteria and Sub criteria should be identified. This step is done by conducting interview an expert form the company that knows well about vendor selection.

\section{4) Create Network of Analytical Network Process}

After conducting the interview about interdependency between criteria and sub criteria, the network is then created by using Super Decision Software. The objective of this step is to shows the interdependency in a network form and to shows the feedback in the criteria.

\section{5) Identify Weight of Criteria and Sub Criteria}

This step is done by using questionnaire, which is pairwise comparison questionnaire. The questioner is made based on the Analytical Network Process. The objective of this step is to identify the weight of criteria and sub criteria in vendor selection. This weight of criteria and sub criteria will be used to determine the final score of vendor. The respondent of the questioner is from the company that has importance toward the problem in this research and has well knowledge 
about criteria of vendor selection.

6) Calculate Geometric Mean

After obtaining the result of pairwise comparison questionnaire from several respondents, the geometric mean should be calculated to get the mean from several respondents.

\section{7) Calculate Consistency Ratio}

This step is done to determine the consistency of respondent's answer. Consistency ratio is a parameter that used to examine the consistency of pairwise comparison result. The geometric mean also can be used to calculate consistency ratio. The function of consistency ratio is to validate the questionnaire. If the consistency ratio is less than 0.1 , the questionnaire is consistent. This step is done by using super decision software.

8) Calculate weight of criteria and sub criteria (Super Decision Software)

The result of geometric mean will be used as an input in pairwise comparison in super decision software. The output of this calculation is Unweighted Super matrix, Weighted Super Matrix and Limiting Super Matrix. This Limiting Super Matrix is the final weight of Sub Criteria and will be used to calculate the final score of vendor.

\section{9) Identify Weight of Vendor}

This step is done by using questionnaire, which is rating scale questionnaire. The objective of this step is to determine the score of vendor. The score of vendor will be used to calculate the final score of vendor.

\section{0) Transform Ordinal Scale into Interval Scale}

The rating scale questionnaire is ordinal scale; thus it should be transformed into interval scale by using methods successive interval before it is being used to calculate the final score.

\section{1) Final Score}

In this step, the rank of vendor will be defined. This step is done by multiplying the score of vendors that is already being transformed into interval scale with the weight of sub criteria that already being calculated by using super decision.

\section{2) Analysis}

In this step, the result of data collection is analyzed and will be discussed in order to find the result of the research.

\section{Result and Discussion}

The research result will be explained as follows. 


\subsection{Identify Criteria and Sub Criteria}

This step is done by using previous research and interview an expert. The expert is from multi source section in procurement department. He has experience for more than five years in that section. There are 5 criteria with 17 sub criteria. Those 5 criteria are Quality, Price, Delivery, Partnership Relationship, and Service. Those 17 sub criteria are shows in Table 1 (Appendices).

\subsection{Identify Interdependency between Criteria and Sub Criteria}

There are two kinds of interdependency, the first one is outer dependency and second one is inner dependency. Outer dependency is the dependency between one clusters to another clusters. Inner dependency is the dependency between the nodes in same cluster. In this research, the cluster is the criteria itself and the node is the sub criteria. This step is done by interviewing an expert from multi-source section in Procurement Department. The expert has experience in multi-source section for more than five years. This step is done to determine the interdependency in every criterion and every sub criteria.

\subsection{Create Network of Analytical Network Process}

This step is done by using super decision software. Super decision software is software that implements the analytical network process for multi criteria decision making by using dependency and feedback. The input of this step is the result of the interdependency interview. The objective of this step is to show the interdependency in a network form. The figure 1 below is the network of Analytical Network Process. It can be seen in figure 1 , every criteria has the relation to another criteria. As can be seen also in figure 1, almost all of criteria have feedback except criteria delivery. A feedback shows that there is inner dependency between sub criteria in same criteria.

\subsection{Identify Weight of Criteria and Sub Criteria}

This step is done by using pairwise comparison questionnaire. The respondents of this questionnaire are expert that have well knowledge about vendor selection and have importance toward the problem in this research. There are nine people as respondents in this questionnaire from three departments, which are Procurement Department, Warehouse Department, and Quality Department.

Procurement Department has responsibility to purchase plates and spare parts. Warehouse Department has responsibility to receive the plates and spare parts from vendor that already ordered by Procurement. Quality Department has responsibility to check the quality of the plates and spare parts that already received by warehouse department.

\subsection{Calculate Geometric Mean}

Geometric mean is an average that indicates the central tendency of a set of numbers by using the product of their values itself. The objective of calculating geometric mean is to accumulate the respondent answer in a formula in order to make the decision. In other word, geometric mean is the average of the respondent answer. The result of pairwise comparison questionnaire should be inputted in super decision software to calculate the weight of each sub criteria. But, since the respondents of this research are more than 1 , the calculation of geometric mean is required. The data that used is the pairwise comparison questionnaire result from all respondents and for all criteria and sub criteria. 
The Table 2 (appendices) shows the geometric mean of sub criteria quality (Quality of Product).

\subsection{Calculate Consistency Ratio}

Consistency ratio is a parameter that used to examine the consistency of pairwise comparison result. It used to examine the consistency of respondent answer. There are two methods to calculate the consistency ratio. The first is by manual method and the second is by using super decision software. In this research, the calculation of consistency ratio is done by using super decision software. To calculate the consistency ratio by using super decision, it is required to input the result of geometric mean for all criteria and sub criteria into pairwise comparison in super decision. By inputting the geometric mean into pairwise comparison in super decision, the consistency ratio can directly be determined, which is 0.03233 . In analytical Network Process, the pairwise comparison result is consistent if the Consistency Ratio is less than 0.1 (Saaty 2005). Based on the super decision software, the consistency ratio is 0.03233 , which is less than 0.1 . It can be concluded that the pairwise comparison result of this research is consistent. Thus, the next calculation can be done, which is the calculation of super matrix and the final weight of every sub criteria.

\subsection{Calculate Weight of Criteria and Sub Criteria}

This step consists of three super matrixes, which are unweighted super matrix, weighted super matrix, and the last is limiting matrix. All of these super matrixes are determined by using super decision software. After inputting the geometric mean into pairwise comparison in super decision, the super matrixes can directly being determined. Unweighted super matrix shows the weight of all criteria and sub criteria without the weight of feedback and weight of priorities. Unweigthed super matrix is determined based on the pairwise comparison between cluster (criteria) and node (sub criteria) by entering the Eigen vector column into a matrix that appropriate with the cell. Weighted super matrix shows the weight of priorities and the weight of feedback. Weighted super matrix is determined by multiplying all elements in unweighted super matrix with the number in appropriate cluster matrix until the number in all columns is 1 . The last step is limiting matrix to determine all weight of sub criteria. To determine the limiting super matrix, the weight of weighted super matrix should be increased. It is done by multiplying the weighted super matrix with the weighted super matrix itself until all weight in every column has the same number. The limiting matrix is determining the weight of every sub criteria. The table 3 below shows the summary of weight of every sub criteria. Table 3 shows the weight of every criterion and weight of every sub criteria. Weight of every criterion is obtained by adding all weight of their sub criteria.

\subsection{Identify Weight of Vendor}

This step is done by using numerical rating scale questionnaire. The objective of this step is to find the score of vendor based on the sub criteria that already determined. The respondents of this questionnaire are the same with the respondents of pairwise comparison questionnaire, which are Manager Procurement, Supervisor Procurement, Procurement Administration, Multi Source Section, Raw Material Section, Warehouse Plates Section, Warehouse Spare Parts Section, Quality Plates Section and Quality Spare 
Parts Section. In this questionnaire, respondents should be given the rating of every vendor based on the 17 sub criteria that already determined.

In the questionnaire, there is an indicator for every sub criteria. The objective of indicator is to synchronize the perception about the definition of every sub criteria. This rating scale questionnaire has 5 scales, from 1 until 5 , where 5 is excellent and 1 is very bad. The result of this rating scale questionnaire will be used to calculate the real score of vendor. It should be multiplied by the weight of every sub criteria. The result of this rating scale questionnaire is in ordinal form. It should be transformed first into interval scale so that it can be multiplied by the weight of every sub criteria.

\subsection{Transform Ordinal Scale into Interval Scale}

This step is done by using Method Successive Interval (MSI). The objective of this step is to transform the ordinal scale into interval scale. The result of rating scale questionnaire is in the ordinal scale. Ordinal scale cannot be processed with interval scale. Since weight of sub criteria is in interval scale, the transformation of ordinal scale from rating scale questionnaire result is required. It can be done by using method successive interval. After all the data from all respondents are transformed into interval scale, the answers of the respondents are averaged. The average interval scale will be used for the final step of vendor selection.

\subsection{Calculate Final Weight of Vendor}

This is the last step for data calculation and analysis in this research. After obtaining the weight of every sub criteria and get the interval form of rating scale questionnaire, the final weight of vendor can be calculated. The final weight of vendor can be done by multiplying the weight of vendor with the interval form of vendor score that was obtained from the rating scale questionnaire. The following formula is to calculate the final score of vendor (Nurmianto and Nurhadi 2006):

Final Score $=$ Weight $\mathrm{x}$ Score

Where

Final Score : Final score of vendor

Weight : Weight of every sub criterion from pairwise comparison

Score $\quad:$ The interval scale of vendor score

When it compared with the result of previous system of vendor selection of this company there are some differences. As known before that the previous system is only based on delivery time. But, by using method Analytical Network Process and doing some interview and questionnaire, there are 5 criteria and $17 \mathrm{sub}$ criteria that appropriate with vendor selection in the company. Figure 2 shows the comparison between the result of previous system and the analytical network process result that shows in Figure 3.

As can be seen in figure 2, the first rank of vendor selection based on the previous system is Vendor CD with $0 \%$ of tardiness. As explained before, to make the vendor selection more accurate, more appropriate criteria and sub criteria are needed. Evidently, by this 
research, the first rank of vendor selection is vendor GH where the vendor $\mathrm{CD}$ is in the fourth place. It can be seen in figure 3. Vendor $\mathrm{MN}$ is the last rank in the previous system because of high tardiness percentage which is $100 \%$. But, as explained before, this $100 \%$ is only from one total delivery. As explained before, the percentage of tardiness is not enough to assess the vendor. By this research, Vendor $\mathrm{MN}$ is in the sixth place. Based on the result of this research, Vendor OP has the smallest rank where in the previous system result Vendor OP is in the fourth place. Based on this research, it can be concluded that Analytical Network Process is an appropriate method for the company to be the system of vendor selection with 5 criteria, which are Quality, Price, Delivery, Partnership Relationship and Service with 17 sub criteria that explained before.

\section{Conclusion}

The aim of this research is to find the best vendor by developing several criteria and sub criteria and using analytical network process. From this study it can be concluded that appropriate criteria and sub criteria for vendor selection have been determined using previous research and interview an expert. There are 5 appropriate criteria and 17 appropriate sub criteria for vendor selection. Using Analytical Network Process, the interdependency between 5 criteria and 17 sub criteria of vendor selection can be determined. Based on the ANP results, almost all of criteria have feedback, which means in almost all of criteria there are inner dependence between the criteria itself. Furthermore, the rank of vendor can be defined. Vendor that has the highest score is vendor GH with total score 3.057 out of 5 and long term relationship sub criterion has the highest weights.

The Analytical Network Process method can be used to select the vendor in the company for long period. It is recommended for future research to find another appropriate method to select the vendor. There are several methods that can be used for vendor performance selection such as AHP, Fuzzy AHP, Fuzzy ANP, Data Envelopment Analysis and PROMETHEE. It is also recommended to add the indicator certifications in sub criterion guaranty such as ISO 14000, ISO 9000 and SNI. 


\section{References}

Ellram, Lisa M. and Martha C. Cooper (1990). Supply Chain Management, Partnerships, and the Shipper-Third-Party Relationship. The International Journal of Logistics Management, 1(2), 1-10.

Esposito, E.., \& Passaro, R. (2009). The Evolution of Supply Chain Relationships: An Interpretative Framework Based on the Italian Inter-industry Experience. Journal of Purchasing and Supply Management, 15(2), 114-126.

Florez-Lopez, R. (2007). Strategic supplier selection in the added-value perspective: A CI approach. Information Sciences, 177(5): 1169-1179

Handayani, Niken. (2009). Evaluasi Performa Supplier Dengan Metoda Fuzzy AHP di PT Garuda Indonesia. FT UI.

Kurniawati, Dewi et. al (2013). Kriteria Pemilihan Pemasok Menggunakan Analytical Network Process. Jurnal Teknik Industri, 15(1),25-32.

La Londe, Bernard J. and James M. Masters (1994). Emerging Logistics Strategies: Blueprints for the Next Century. International Journal of Physical Distribution and Logistics Management, 24(7), 35-47.

Lambert, Douglas M., James R. Stock, and Lisa M. Ellram (1998). Fundamentals of Logistics Management. Boston, MA: Irwin/McGraw-Hill, Chapter 14.

Mulyati, Erna and Faizal, Muhammad Abdul (2012). Sistem Penilaian Kinerja Supplier Pallet Di PT. PINDO Deli Pulp and Paper Mills Dengan Menggunakan Metode Analytic Network Process.

Nurmianto, E. and Nurhadi S. (2006). Perancangan Penilaian Kinerja Karyawan Berdasarkan Kompetensi Spencer dengan Metode Analytical Hierarchi Process (Studi Kasus di Sub Dinas Pengairan, Dinas Pekerjaan Umum Kota Probolinggo). Jurnal Teknik Industri 8(1): 40-53

Saaty, T. L. (2005). Theory and Applications of the Analytic Network Process. Pittsburgh, PA: RWS Publications, 4922 Ellsworth Avenue, Pittsburgh, PA 15213

Surjasa, Dadang, Pudji Astuti, and Hario Nugroho (2006). Usulan Supplier Selection Dengan Analitycal Hierarchy Process Dan Penerapan Sistim Informasi Dengan Konsep Vendor Managed Inventory Pada PT. ABC. pp. 1-12

Tookey, J.E, and S. Thiruchelvam (2011). Evolving Trends of Supplier Selection Criteria and Methods. International Journal of Automotive and Mechanical Engineering (IJAME), 4, 437-454.

Jennings, J.E., Breitkreuz, R.S. and James, A.E., (2013). When family members are also business owners: Is entrepreneurship good for families?. Family Relations, 62(3), 472-489.

Lam, W., (2011). Dancing to two tunes: Multi-entity roles in the family business succession process. International Small Business Journal, 29(5), 508-533.

Michael-Tsabari, N. and Weiss, D., 2015. Communication traps: Applying game theory to succession in family firms. Family Business Review, 28(1), pp.26-40. 
Nordqvist, M. and Melin, L., (2010). The promise of the strategy as practice perspective for family business strategy research. Journal of Family Business Strategy, 1(1), $15-25$.

Salvato, C., Minichilli, A. and Piccarreta, R., (2012). Faster route to the CEO suite: Nepotism or managerial proficiency?. Family Business Review, 25(2), 206-224.

Sorenson, R.L. and Bierman, L., (2009). Family capital, family business, and free enterprise. Family Business Review, 22(3), 193-195.

Stewart, A. and Hitt, M.A., (2012). Why can'ta family business be more like a nonfamily business? Modes of professionalization in family firms. Family Business Review, 25(1), 58-86. 


\section{Appendices}

\section{Table 1: Criteria and Sub Criteria}

\begin{tabular}{|c|c|c|}
\hline CRITERIA & SUB CRITERIA & SOURCE \\
\hline \multirow{3}{*}{ Quality } & Quality of Product & Surjasa (2006) \\
\hline & $\begin{array}{ll}\text { Conformance } & \text { with } \\
\text { Specifications } & \end{array}$ & Surjasa (2006) \\
\hline & Consistent Quality & Surjasa (2006) \\
\hline \multirow{4}{*}{ Price } & Competitive Price & Handayani (2009) \\
\hline & Negotiation & Handayani (2009) \\
\hline & Term of Payment & Handayani (2009) \\
\hline & Price Stability & Company’s Expert (2015) \\
\hline \multirow{4}{*}{ Delivery } & Accuracy of Order Quantity & Handayani (2009) \\
\hline & Accuracy of Product Order & Handayani (2009) \\
\hline & Prevention of Damage & Handayani (2009) \\
\hline & On Time Delivery & Company’s Expert (2015) \\
\hline \multirow{3}{*}{$\begin{array}{l}\text { Partnership } \\
\text { Relationship }\end{array}$} & Past Experience & Kurniawati, Dewi, et.al (2013) \\
\hline & Financial Strength of Vendor & Kurniawati, Dewi, et.al (2013) \\
\hline & Long Term Relationship & Company's Expert (2015) \\
\hline \multirow{3}{*}{ Service } & Guaranty & Kurniawati, Dewi, et.al (2013) \\
\hline & Flexibility & Company’s Expert (2015) \\
\hline & $\begin{array}{l}\text { Responsiveness Toward Urgent } \\
\text { Order }\end{array}$ & Company’s Expert (2015) \\
\hline
\end{tabular}

\section{Table 2: Geometric Mean of Sub Criteria of Quality (Quality of} Product)

\begin{tabular}{|l|c|c|c|}
\hline Respondent & QI X QI & Q2 X Q1 & Q3 X Q1 \\
\hline R1 & 1 & 1 & 1 \\
\hline R2 & 1 & 3 & 5 \\
\hline R3 & 1 & 4 & 4 \\
\hline R4 & 1 & 1 & 3 \\
\hline R5 & 1 & 1 & 1 \\
\hline R6 & 1 & 1 & $1 / 2$ \\
\hline R7 & 1 & $1 / 8$ & 8 \\
\hline R8 & 1 & $1 / 6$ & 6 \\
\hline R9 & 1 & $1 / 8$ & 8 \\
\hline MULTIPLY & 1 & 0.03125 & 11520 \\
\hline 1/9 & $\mathbf{1}$ & $\mathbf{0 . 6 8}$ & $\mathbf{2 . 8 3}$ \\
\hline
\end{tabular}


Table 3: Weight of Sub Criteria

\begin{tabular}{|c|c|c|c|}
\hline Criteria & Weight & Sub Criteria & Weight \\
\hline \multirow{3}{*}{ Quality } & \multirow{3}{*}{0.2036} & Quality of Product & 0.0798 \\
\hline & & $\begin{array}{l}\text { Conformance with } \\
\text { Specification }\end{array}$ & 0.0659 \\
\hline & & Consistent Quality & 0.0579 \\
\hline \multirow{4}{*}{ Price } & \multirow{4}{*}{0.2487} & Competitive Price & 0.1031 \\
\hline & & Negotiation & 0.0918 \\
\hline & & Term of Payment & 0.0412 \\
\hline & & Price Stability & 0.0125 \\
\hline \multirow{4}{*}{ Delivery } & \multirow{4}{*}{0.1850} & $\begin{array}{c}\text { Accuracy of Order } \\
\text { Quantity }\end{array}$ & 0.0166 \\
\hline & & $\begin{array}{c}\text { Accuracy of Product } \\
\text { Order }\end{array}$ & 0.0585 \\
\hline & & Prevention of Damage & 0.0533 \\
\hline & & On Time Delivery & 0.0567 \\
\hline \multirow{3}{*}{$\begin{array}{l}\text { Partnership } \\
\text { Relationship }\end{array}$} & \multirow{3}{*}{0.2377} & Past Experience & 0.0517 \\
\hline & & $\begin{array}{c}\text { Financial Strength of } \\
\text { Vendor }\end{array}$ & 0.0351 \\
\hline & & $\begin{array}{l}\text { Long Term } \\
\text { Relationship }\end{array}$ & 0.1509 \\
\hline \multirow{3}{*}{ Service } & \multirow{3}{*}{0.1250} & Guaranty & 0.0784 \\
\hline & & Flexibility & 0.0185 \\
\hline & & $\begin{array}{c}\text { Responsiveness } \\
\text { Toward Urgent Order }\end{array}$ & 0.0281 \\
\hline
\end{tabular}




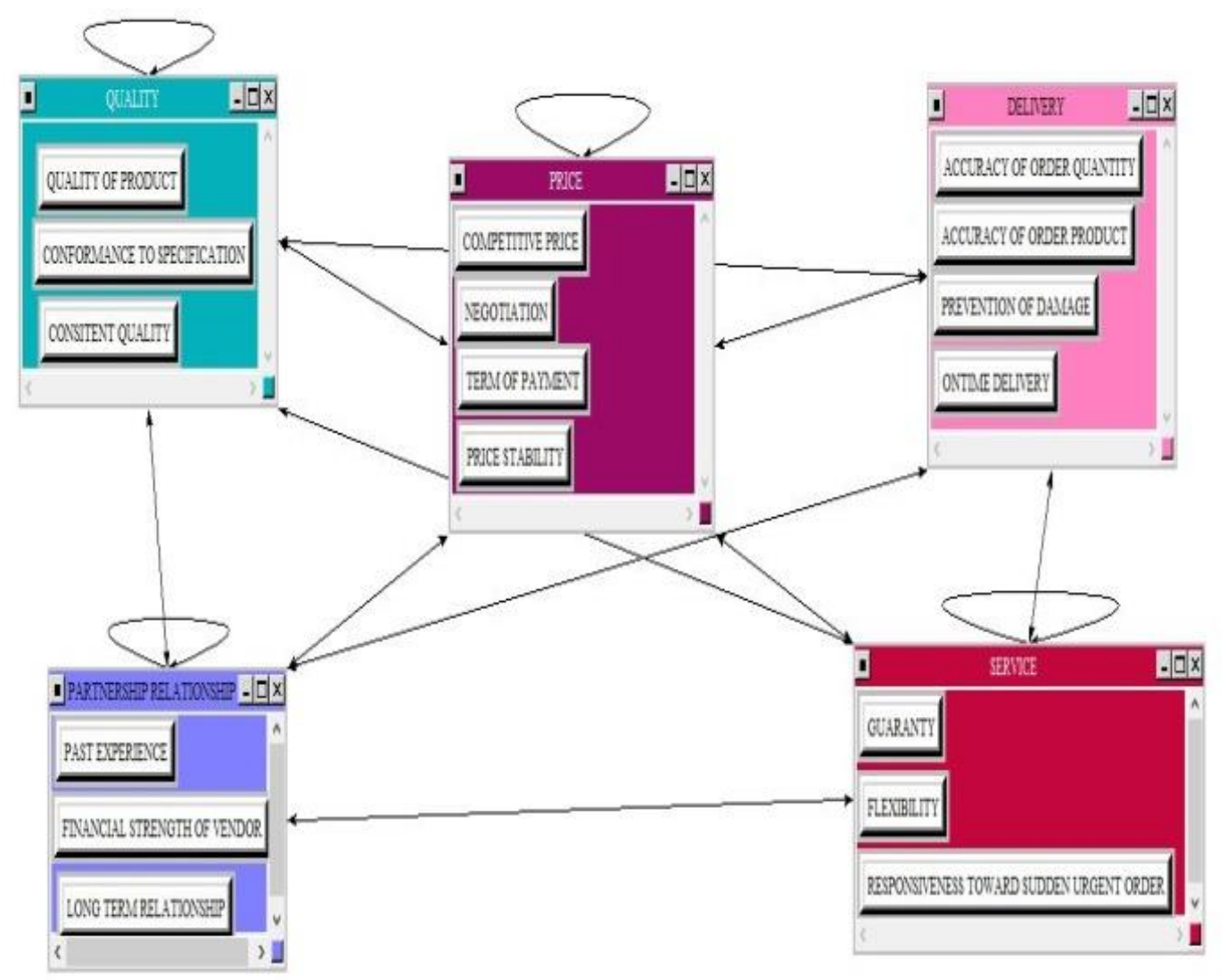

Figure 1: Network of Analytical Network Process 


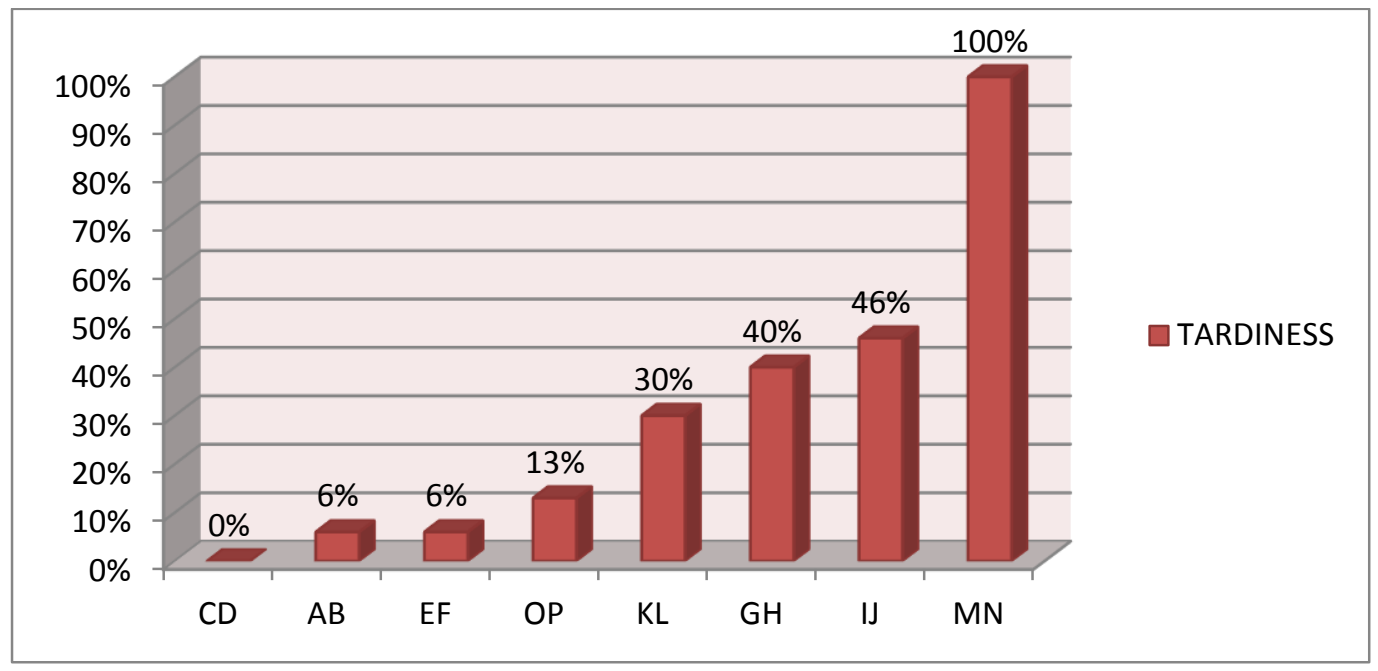

Figure 2 The Result of Previous System

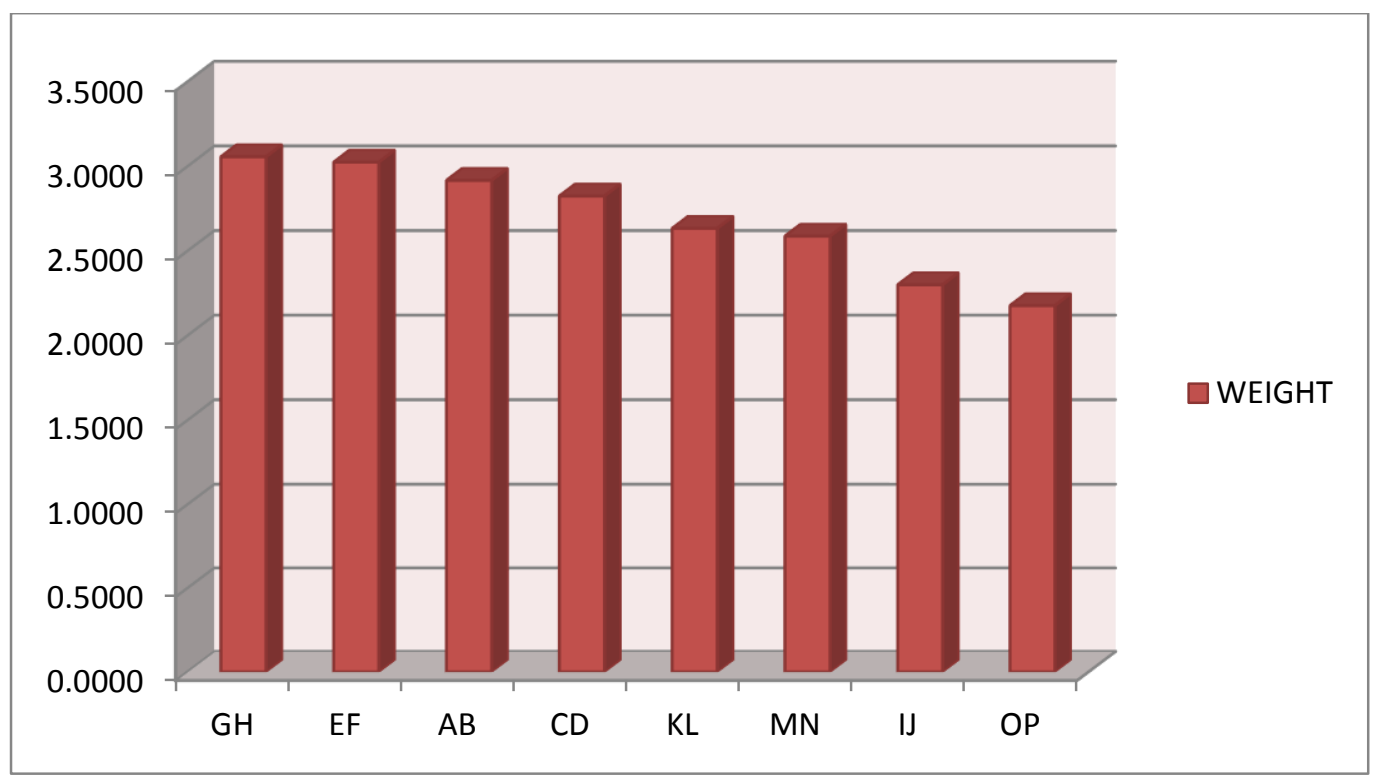

Figure 3 The ANP Result 